\title{
PENGARUH TAYANGAN MY TRIP MY ADVENTURE DI TRANS TV TERHADAP PENGETAHUAN WISATA SISWA
}

\author{
Tegar Prasetiyo ${ }^{1}$, Tina Agustari ${ }^{2}$
}

\author{
Sekolah Tinggi Ilmu Komunikasi Interstudi \\ tegarprasetiyo99@gmail.com
}

$\underline{\text { Received : } 30 \text { July } 202 \text { |Reviewed: } 4 \text { August } 2021 \text { | Accepted: } 20 \text { August } 2021}$

\begin{abstract}
ABSTRAK
Televisi sebagai medium komunikasi massa memiliki fungsi informasi, mendidik, dan menghibur. Salah satu program TV yang memiliki fungsi tersebut adalah program My Trip My Adventure. Tujuan dari penelitian ini untuk melihat dampak dari tayangan My Trip My Adventure terhadap pengetahuan wisata siswa. Apakah siswa yang telah menonton tayangan My Trip My Adventure akan mendapatkan pengetahuan wisata. Pengaruh tersebut diungkap berdasarkan ketertarikan pada tayangan My Trip My Adventure dan ekspektasi pengembangan kemampuan kognitif individu terhadap informasi wisata dari tayangan ini. Metode penelitian yang digunakan adalah kuantitatif dengan paradigma positivisme. Penelitian dilakukan dengan pengumpulan data primer melalui survey, kemudian dianalisis dengan menggunakan metode analisis deskriptif. Populasi penelitian ini adalah siswa SMKN 29 Jakarta, kelas 10 tahun ajaran 2020-2021 yang berjumlah 338 siswa, dengan sampel minimal sebanyak 78 siswa. Hasil dari penelitian ini menunjukkan tayangan My Trip My Adventure yang menampilkan wisata Indonesia cenderung memengaruhi bagaimana individu memproses informasi tentang potensi wisata Indonesia dan ragam budaya Indonesia. Selain itu tayangan My Trip My Adventure yang mengedukasi untuk peduli lingkungan memengaruhi keputusan penonton untuk ikut menjaga alam. Kesimpulan dari penelitian ini adalah tayangan My Trip My Adventure di Trans Tv memberi pengaruh yang signifikan terhadap pengetahuan wisata siswa.
\end{abstract}

Kata kunci: Tayangan My Trip My Adventure, media televisi, pengetahuan wisata siswa.

Korespondensi:

Sekolah Tinggi Ilmu Komunikasi Interstudi

Jalan Wijaya II No. 62 Kebayoran Baru, Jakarta

E-mail: tegarprasetiyo99@gmail.com ～JURNAL ILMIAH DINAMIKA SOSIAL 5 (1) 2021|87 


\begin{abstract}
Television as a medium of mass communication has the function of informing, educating, and entertaining. One of the TV programs that have this function is My Trip My Adventure program. The purpose of this study was to see the impact of My Trip My Adventure on students' travel knowledge. Will students who have watched My Trip My Adventure get travel knowledge. The effect is revealed based on interest in My Trip My Adventure and expectations of the development of individual cognitive abilities on tourist information from this show. The research method used is quantitative with a positivism paradigm. The research was conducted by collecting primary data through surveys, then analyzed using descriptive analysis methods. The population of this study was students of SMKN 29 Jakarta, class 10 for the 2020-2021 academic year, totaling 338 students, with a minimum sample of 78 students. The results of this study indicate that My Trip My Adventure shows that Indonesian tourism tends to affect how individuals process information about Indonesia's tourism potential and Indonesian cultural diversity. In addition, the My Trip My Adventure program, which educates people to care about the environment, influences the audience's decision to participate in protecting nature. This study concludes that My Trip My Adventure on Trans Tv has a significant effect on students' travel knowledge.
\end{abstract}

Key word: My Trip My Adventure shows, television media, student tourism knowledge.

\title{
PENDAHULUAN
}

Seiring berkembangnya zaman, kebutuhan manusia akan informasi juga semakin meningkat. Ladjamudin dalam (Hermawan, Hidayat, and Utomo 2016) berpendapat informasi adalah data yang telah diolah menjadi bentuk yang lebih berarti dan berguna bagi penerimanya untuk mengambil keputusan masa kini maupun masa yang akan datang. Berkembangnya media telekomunikasi serta informasi, seperti internet, radio, televisi, satelit, dan surat kabar merupakan tanda meningkatnya kebutuhan manusia akan informasi. Masyarakat harus pintar memilih tayangan sesuai kebutuhan mereka dengan banyaknya media massa yang hadir saat ini. Menurut Bungin dalam (Habibie 2018) media massa dimaknai dengan informasi serta media komunikasi yang melaksanakan penyebaran informasi dengan cara masal serta bisa diakses oleh khalayak, dilihat dari sudut arti, media massa adalah alat untuk penyebaran opini, isi berita, hiburan, komentar, dll. Menurut McLuhan dalam jurnal (Mustika and Anggraini 2019), media massa adalah perpanjangan alat indra kita. Dengan media massa kita memperoleh informasi tentang benda, orang atau tempat yang belum pernah kita lihat atau belum pernah kita kunjungi secara langsung. Realitas yang ditampilkan oleh media adalah realitas yang sudah diseleksi. Salah satu media massa yang paling banyak digemari adalah televisi. Televisi merupakan kombinasi dari film serta radio. Suatu program siaran televisi dapat dilihat dan didengar karena adanya pemancar televisi yaitu program ditransmisikan oleh satelit langsung ke antena parabola. (Effendy dalam Friska 2016). Televisi dapat meningkatkan kreativitas dan 
menambah pengetahuan. Pemilihan tayangan televisi yang tepat juga dapat menunjang pendidikan di sekolah (Ahmadi dalam Pratama et al., 2019)

Program televisi sebagai media komunikasi massa berpengaruh terhadap pengetahuan, menurut Efendy dalam (Qudratullah 2016) fungsi komunikasi massa ialah sebagai informasi, pendidikan, serta mempengaruhi. (Qudratullah 2016) menyimpulkan beberapa fungsi komunikasi yang disebutkan para ahli, yang pertama to inform, fungsi terpenting pada komunikasi massa ialah fungsi informasi. Berbagai berita yang disajikan merupakan komponen paling utama untuk mengetahui fungsi informasi ini (Nurudin dalam Qudratullah, 2016). Dari aspek ini, komunikasi massa menyiapkan informasi pada dunia dan masyarakat tentang kondisi serta peristiwa, memudahkan adaptasi, kemajuan, inovasi serta memperlihatkan hubungan kekuasaan (Abdul Halik dalam Qudratullah, 2016). Media massa merupakan penyebar informasi bagi masyarakat. Yang kedua to educate, media massa adalah sarana pendidikan untuk masyarakat (mass education), karena banyak menampilkan hal yang bersifat mendidik. Melalui pengajaran etika, nilai dan aturan-aturan yang berlaku untuk audiens merupakan salah satu cara mendidik, yang dipakai media massa. Dengan diskusi, artikel, drama, dan cerita media massa melakukannya (Elvinaro Ardianto dkk dalam Qudratullah, 2016). Yang ketiga to influence, fungsi mempengaruhi dari media massa ada pada iklan artikel, features, editorial atau tajuk dan lainnya. Dengan iklan-iklan yang disuguhkan surat kabar maupun televisi audiens dapat terpengaruh (Elvinaro Ardianto dkk dalam Qudratullah, 2016). Yang keempat to entertaint, karena khalayak masyarakat memakai televisi untuk hiburan, maka fungsi hiburan menempati posisi tertinggi dibanding fungsi yang lainnya. Sedangkan media cetak biasanya lebih mengutamakan informasi dibanding hiburan. Namun, media cetak juga harus memberikan fungsi hiburan (Nurudin dalam Qudratullah, 2016).

Dari teori fungsi komunikasi yang dipaparkan di atas, dapat disimpulkan bahwa tayangan televisi tidak hanya bisa menghibur tetapi juga memberi manfaat lebih seperti pendidikan dan melahirkan pengetahuan. Media televisi bisa berpengaruh baik dengan menjadikannya sebagai alat informasi yang bisa menambah pengetahuan siswa, serta bisa menambah prestasi belajar siswa (Jayarni, Imra, and Septiwiharti 2014). Televisi memiliki peran positif terhadap pengetahuan siswa di sekolah. Meningkatkan aspek pembelajaran siswa serta mampu mempersuasi, memotivasi serta mengubah sikap dan perilaku. Pearson, dkk. Dalam (Hartati 2012) mengatakan pendekatan afektif kognitif untuk menumbuhkan karakter baik serta 
menurunkan pemikiran irasional yang membuat karakter tidak baik. Suatu pendekatan yang berpusat pada berpikir serta proses mental untuk merubah karakter serta sering mengaitkan pelatihan, kontrol pikiran, pengembangan keterampilan, dan teknik-teknik serta proses-proses yang berorientasi kognitif lainnya disebut dengan pendekatan kognitif (Mappiare dalam Hartati 2012). Kognitif artinya pengetahuan serta persepsi, dan memiliki arti proses pemikiran. Gagasan utama pada pendekatan kognitif ialah pemahaman pada sebuah kejadian sangat berdampak kepada perilaku, psikologis serta respon emosional pada kejadian tersebut (Greenberger \& Padesky dalam Hartati 2012).

Ada beragam jenis program tayangan televisi. Masing-masing memuat fungsi edukasi, informasi, mempengaruhi dan menghibur. Salah satu program yang memuat keempat fungsi tersebut adalah program My Trip My Adventure. Tayangan ini memiliki fungsi menyiarkan informasi, dalam tayangan tersebut. Tayangan my trip my adventure menyediakan informasiinformasi mengenai panduan tempat wisata dan tempat liburan di Indonesia. Tayangan ini mengajak penonton dan juga masyarakat setempat untuk tetap mencintai dan peduli lingkungan, salah satunya membuang sampah pada tempatnya dan menyediakan sarana tempat sampah di lingkungan mereka berada. Tayangan My Trip My Adventure juga memiliki fungsi untuk mendidik, tidak jarang pembawa acara mengingatkan penonton dengan pendekatan yang lebih populer yakni menggunakan kalimat "buang sampah sembarangan itu gak asik bro", tayangan My Trip My Adventure juga mengenalkan kepada penonton tentang geografi wisata Indonesia, tradisi, budaya, dan kearifan lokal. Tayangan ini juga berfungsi untuk mempengaruhi, diharapkan dengan ajakan para host untuk peduli dan mencintai lingkungan, masyarakat bisa lebih sadar dan lebih peduli terhadap lingkungan. Selain itu tayangan My Trip My Adventure juga memiliki fungsi menghibur, dengan menampilkan artis muda yang gemar petualangan dengan semangat menjaga alam serta memperkenalkan budaya Indonesia dengan cara mendatangi tempat-tempat indah di Indonesia. My Trip My Adventure merupakan program acara dari stasiun televisi Trans TV. Tayangan ini tidak hanya bertujuan untuk menghibur, tetapi juga untuk informasi serta konsisten menyuguhkan petualangan berbeda di tiap minggunya. Tayangan ini akan menampilkan hal nyata serta menarik yang dilakukan pembawa acaranya, semacam gurauan mereka, kekaguman mereka dengan budaya serta tempat yang ditemui, interaksi sosial, bahkan mereka berani mencoba banyak hal (Friska 2016).

Tayangan My Trip My Adventure mempunyai muatan positif pada pengetahuan dan perkembangan kognitif penonton. Meningkatkan kemampuan seseorang untuk memahami 
tayangan yang ditampilkan. Tayangan ini menghasilkan pengetahuan tentang wisata di Indonesia. Penonton bisa mempelajari geografi wisata, karakteristik sumber daya wisata yang ada di setiap daerah di Indonesia. Mempelajari potensi wisata serta keunikan daya tarik wisata yang dikunjungi. Tayangan ini merupakan tayangan yang menampilkan pengetahuan mendasar mengenai berbagai pengetahuan wisata yang dikemas dengan menarik. Program tayangan $M y$ Trip My Adventure bisa menginspirasi dan memotivasi penontonya untuk menanamkan nilainilai cinta budaya, tradisi, lingkungan, serta kearifan lokal yang bisa diterapkan dalam kehidupan sehari-hari.

Manfaat akademisi dari penelitian ini diharapkan dapat digunakan sebagai bahan pertimbangan dan referensi peneliti lain untuk melakukan penelitian yang relevan. Selanjutnya manfaat praktisi dari penelitian ini ialah, hasil penelitian ini dapat bermanfaat bagi para praktisi media penyiaran televisi mengenai pengaruh tayangan program televisi terhadap pengetahuan siswa.

Berdasarkan latar belakang di atas, dapat diketahui bahwa rumusan masalah dalam penelitian ini ialah sejauh mana pengaruh tayangan My Trip My Adventure di Trans TV terhadap pengetahuan wisata siswa.

\section{KAJIAN TEORI}

\section{Komunikasi Massa}

Hadirnya komunikasi massa mempunyai peran penting untuk memperbanyak bentuk komunikasi tatap muka, bermakna, serta menebarkan budaya massa baru, terutama di abad ke19 seiring dengan majunya teknologi informasi serta komunikasi (Abdul Halik 2013). Komunikasi yang memakai media massa merupakan komunikasi massa, komunikasi massa membutuhkan media massa semacam televisi, radio, majalah, surat kabar. Yang lebih detail menekan pemakaian media massa disebutkan oleh Bittner pada (Setiawan 2016) bahwa pesan yang disampaikan melalui media massa pada sejumlah besar orang disebut dengan komunikasi massa. Sedangkan menurut Dennis dan De Fleur dalam (Setiawan 2016) terjadi perbedaan pada hal konsekuensi memakai media, konsekuensi mempunyai khalayak luas serta beraneka ragam, efek kultur serta sosial. Komunikasi massa akan banyak dilaksanakan pada masyarakat industry, karena proses produksi pesan tidak bisa dilaksanakan pada individu, tetapi harus lembaga, serta membutuhkan suatu teknologi tertentu (Ardianto 2014). 


\section{Televisi Medium Komunikasi Massa}

Televisi pada dasarnya merupakan media komunikasi yang bisa didengar serta dilihat. Manfaat televisi yaitu (Nurchayati 2015): 1) Fungsi Informasi, televisi bukan sekedar dalam bentuk siaran pandang mata, mendengar berita disertai gambar-gambar yang faktual. Tetapi televisi juga menayangkan bentuk lain seperti ceramah, diskusi, serta komentar-komentar. Maka dari itu, televisi dianggap oleh khalayak dengan media yang bisa memuaskan pemirsa dirumah, dibanding media lain. 2) Fungsi Pendidikan, televisi merupakan salah satu alat ampuh untuk menayangkan pendidikan pada khalayak serta bisa disampaikan dengan cara simultan. Sejalan dengan arti serta tujuan pendidikan, yaitu mencerdaskan, menambah penalaran serta pengetahuan, dan wawasan masyarakat, maka televisi menyiarkan acaranya dengan cara terjadwal dan teratur seperti belajar matematika, bahasa Indonesia, forum diskusi, sejarah dll. Selain tayangan tersebut, televisi juga menyiarkan tayangan pendidikan yang sifatnya informal seperti legenda, sandiwara, dll. 3) Fungsi Hiburan. Televisi adalah sarana hiburan yang sangat menarik. Hal ini dikarenakan tayangan yang disajikan televisi untuk program hiburan sangat beragam. Sehingga khalayak bisa menikmati tayangan tersebut.

\section{Jenis-Jenis Program Televisi}

Program televisi bisa dibagi beberapa jenis, yaitu: (Morissan 2011). Yang pertama program Berita, program berita dibagi menjadi dua, yang pertama Hard news semua informasi menarik serta penting, yang harus segera disuguhkan oleh media penyiaran karena sifatnya harus secepatnya disiarkan, agar bisa diketahui penonton secepatnya disebut dengan hard news. Berita keras sendiri bisa dibagi menjadi beberapa bentuk berita, yaitu: Straight News, Feature, Infotainment. Program berita yang kedua yaitu, Soft News segala informasi yang menarik serta penting, disuguhkan dengan cara mendalam tetapi tidak bersifat segera disiarkan disebut dengan Soft News. Program yang termasuk bagian dari berita lunak, yaitu: Current Affair, Magazine, Dokumenter, Talk Show. Program televisi yang kedua yaitu, program hiburan, tayangan yang memiliki tujuan menghibur penonton dalam bentuk cerita, permainan, serta musik disebut dengan program hiburan. Program yang masuk bagian hiburan ialah: a) Drama, b) Game Show, program ini bisa dibagi jadi tiga jenis, yaitu: Quiz Show, ketangkasan, Reality Show. (c) Musik, (d) Pertunjukan.

\section{Elemen-Elemen Program Televisi}


Program-program yang sukses mempunyai elemen sebagai berikut (Morissan dalam Wulandari 2015): (1) Konflik, tabrakan karakter atau tabrakan kepentingan antara berbagai tokoh yang terlibat, konflik merupakan salah satu elemen penting di dalam keberhasilan suatu program. (2) Durasi, yang mampu bertahan selama mungkin ialah suatu program yang berhasil. Suatu program itu terdiri atas program yang tidak bertahan lama (nondurable program) dan yang bertahan lama (durable program). (3) Kesukaan, beberapa penonton memilih tayangan yang menampilkan pembawa acara atau pemain utama yang disukainya. (4) Konsistensi, sebuah program sejak awal harus konsisten dengan topik dari karakter program yang disajikannya. (5) Energi, Vane-Gross mendefinisikan energi sebagai kualitas yang menekankan pada kecepatan dan semangat ke dalam cerita dengan menyajikan gambar-gambar yang tidak bisa ditinggalkan oleh penonton. (6) Timing, ketika programmer memilih sebuah program, ia harus bisa memperkirakan timing, apa program tersebut telah sesuai pada zamannya. (7) Tren, ketika programmer memilih program, ia harus mempunyai kesadaran kepada hal-hal yang sedang diminati di masyarakat.

Program My Trip My Adventure tayang di stasiun televisi Trans Tv, dengan durasi 30 menit setiap hari minggu pukul 09.00 WIB. Program ini berjenis dokumenter perjalanan atau travel and lifestyle.

\section{Pengetahuan dalam ranah kognitif}

Pengetahuan adalah sesuatu yang diketahui oleh manusia. Menurut Rakhmat dalam (Friska 2016) yang jadi alat utamanya adalah jiwa "mind" bukan alat indra, disebut dengan pengetahuan. Pengalaman inderawi dengan aktif menafsirkan, melahirkan, mencari makna, mendistorsikan, mengoordinasikan merupakan penafsiran dari jiwa. Berdasarkan pemaparan di atas, semua manusia dapat memperoleh pengetahuan sesuai kemauan serta kebutuhannya lewat panca indra dengan menggunakan kekuatan pemikiran. Sedangkan menurut (Rakhmat dalam Friska, 2016) klasifikasi pengetahuan yaitu sensasi, persepsi dan berfikir.

Menurut Burns dalam Hartati (2012), tujuan dari pendekatan kognitif ialah: (1) Membangunkan pikiran klien, berbicara pada diri sendiri serta melaksanakan interpretasi pada pristiwa yang telah dialami. (2) Bersamaan dengan konselor, klien menyanggah interpretasiinterpretasi yang sudah diambil ataupun mengumpulkan bukti yang mendukung. Suatu pendekatan atau rancangan konseling yang fokus dengan berpikir serta proses mental pada 
merubah perilaku atau modifikasi serta suka melibatkan kontrol pikiran, pengembangan keterampilan, pelatihan, serta segala proses dan teknik yang berorientasi kognitif lainnya disebut dengan pendekatan kognitif (Mappiare dalam Hartati, 2012). Proses pemikiran serta pengetahuan dan persepsi disebut dengan kognitif. Persepsi pada sebuah pengalaman atau peristiwa sangat berpengaruh pada respon perilaku, psikologis serta emosional kepada peristiwa itu merupakan ide pokok di dalam pendekatan kognitif (Greenberger \& Padesky dalam Hartati, 2012).

Komponen dalam struktur sikap, menurut Walgito dalam jurnal (Musrifah 2019), terdapat tiga komponen yang disusun serta saling berkaitan dengan masing-masing komponen. Komponen afektif, komponen konatif, komponen kognitif merupakan komponen dalam struktur sikap.

\section{Wisata}

Pada awalnya, pariwisata berkembang dari pergerakan manusia yang bergerak mencari sesuatu yang belum diketahuinya, mengekspor tempat tempat baru, mendapatkan perjalan baru atau mencari suasana baru. Berdasarkan pengertian di atas, perlahan pengertian pariwisata makin berkembang. Saat ini definisi wisata bermakna perjalanan dimana si pelaku kembali pada tempat asalnya. Perjalanan yang dipakai sebagai bisnis, perjalanan yang bertujuan untuk senang senang atau untuk pendidikan dengan bermacam wilayah yang didatangi, dan memakai jadwal yang terencana. (Murphy dalam Damasdino, 2015). Sedangkan menurut Cooper dalam jurnal (Soedarso, Nurif, and Windiani 2014), serangkaian perjalanan yang dilalui kelompok ataupun individu dari tempat tinggalnya ke tempat lainnya untuk bertujuan wisata serta tidak bertujuan mencari pekerjaan, merupakan definisi dari pariwisata. Kunjungan sifatnya sementara (1 bulan, 1 minggu, 1 hari) serta akhirnya akan kembali lagi ke tempat tinggalnya.

\section{Teori S-O-R (Stimulus, Organism, Respon)}

Objek material dari ilmu komunikasi serta psikologi ialah sama, yakni manusia yang jiwanya melingkupi elemen-elemen: kognisi afeksi, perilaku, konasi, opini serta sikap. Media massa melahirkan dampak yang langsung, cepat dan terarah pada komunikan merupakan asumsi dasar pada model ini. ( $S$-R theory) Stimulus Response Theory, proses aksi-reaksi adalah definisi komunikasi yang ditunjukkan oleh model ini. Tanda nonverbal, kata-kata verbal, kode- 
kode tertentu akan membuat orang lain memberi tindakan secara tertentu, merupakan asumsi dari model ini. Dengan cara negatif ataupun positif pola SOR bisa terjadi, contohnya ketika seseorang menyapa orang lain, lalu dibalas dengan tatapan sinis, maka ini adalah reaksi negatif, tetapi ketika seseorang tersenyum akan dibalas tersenyum, ini adalah reaksi positif (Effendy dalam Friska, 2016).

Stimulus dari penelitian ini ialah tayangan My Trip My Adventure yang juga bagian variabel X (independen). Apakah sesudah melihat tayangan ini penonton bisa mendapatkan pengetahuan wisata. Pengetahuan adalah sesuatu yang diketahui oleh manusia. Menurut Rakhmat dalam (Friska 2016) yang jadi alat utamanya adalah jiwa "mind" bukan alat indra, disebut dengan pengetahuan. Pengalaman inderawi dengan aktif menafsirkan, melahirkan, mencari makna, mendistorsikan, mengoordinasikan merupakan penafsiran dari jiwa. Berdasarkan pemaparan di atas, semua manusia dapat memperoleh pengetahuan sesuai kemauan serta kebutuhannya lewat panca indra dengan menggunakan kekuatan pemikiran. Sedangkan menurut (Rakhmat dalam Friska, 2016) klasifikasi pengetahuan yaitu sensasi, persepsi dan berfikir.

Organisme dari penelitian ini adalah siswa SMKN 29 Jakarta. Diharapkan tayangan $M y$ Trip My Adventure dapat meningkatkan pengetahuan siswa di bidang wisata, seperti geografi wisata, keunikan budaya disetiap daerah, dll. Seperti yang dikatakan (Jayarni, Imra, and Septiwiharti 2014) media televisi untuk siswa bisa berpengaruh baik dengan menjadikannya sebagai alat informasi yang bisa menambah pengetahuan siswa, serta bisa menambah prestasi belajar siswa. Suatu proses yang sadar tujuan disebut juga dengan pendidikan. Suatu usaha untuk memberi rumusan hasil yang diharapkan oleh siswa setelah melakukan pengalaman belajar bisa didefinisikan dengan tujuan (Sadirman dalam Hamdu \& Agustina, 2011). Menurut Slameto dalam (Hamdu and Agustina 2011) sebaris kegiatan jiwa raga untuk mendapat sesuatu perubahan perilaku sebagai hasil dari pengalaman seseorang dalam interaksi pada lingkungannya menyangkut kognitif, afektif, dan psikomotorik disebut dengan belajar. Siswa mengalami proses dari tidak tahu menjadi tahu dalam belajar.

Adapun respon yang juga menjadi variabel Y pada penelitian ini ialah pengetahuan wisata siswa yang tercipta sesudah melihat tayangan ini. Salah satu penggagas psikologi kognitif ini ialah teori kognitif George Miller. Bersumber dari sebutan "Cognitive” dari kata "cognition" ataupun kognisi yang berarti manusia yang memakai akalnya untuk berpikir. Proses mendapatkan pengetahuan termasuk kesadaran, perasaan dan lainnya, atau cara untuk mencari 
sesuatu dengan proses penafsiran, serta pengenalan lingkungan oleh seseorang, pengalaman sendiri, hasil dari mendapatkan pengetahuan merupakan definisi kognisi secara luas (Walgito dalam Friska, 2016). Fungsi kerja utama dari otak kita merupakan definisi proses berpikir menurut perspektif psikologi kognitif ini. Bagian psikologi yang mendalami proses mental termasuk bagaimana orang mengingat, belajar, merasakan serta berfikir disebut dengan psikologi kognitif. Suatu proses perubahan pemahaman serta persepsi yang tidak selamanya berupa pergantian perilaku yang dapat diperhatikan oleh diri kita, merupakan definisi proses belajar yang diterangkan oleh aliran psikologi kognitif ini. Setiap orang sudah memilki pengetahuan yang berasal dari pengalamannya, yang ada pada diri mereka yang tersusun sangat rapi pada wujud struktur kognitif merupakan asumsi dasar teori kognitivisme ini (Friska 2016).

Pada proses sejarah, pariwisata akhirnya disebut dengan sesuatu kegiatan yang menjanjikan keuntungan. Lalu timbul kemauan dari banyak pihak untuk mempelajari pariwisata itu sendiri, inilah yang menjadikan pariwisata sebagai ilmu pengetahuan baru. Pariwisata sebenarnya mampu sejajar dengan ilmu lainnya, jika dikaji dengan mendalam. Hal tersebut dapat diperhatikan melalui sudut pandang filsafat ilmu ataupun kajian komparatif pada ilmu lainnya atau perbandingan pada pendidikan tinggi pariwisata di lain negara (Suwena and Widyatmaja 2017).

\section{Hipotesis}

Satu macam proposisi yang di rumuskan untuk jawaban tentatif atau salah satu problem, lalu diuji dengan cara empiris, disebut dengan hipotesis (Ulber Silalahi dalam Setiawan, 2016). Di penelitian ini hipotesis berbentuk: Ha : Terdapat pengaruh langsung tayangan My Trip My Adventure terhadap pengetahuan wisata siswa SMKN 29 Jakarta. Ho : Tidak terdapat pengaruh langsung tayangan My Trip My Adventure terhadap pengetahuan wisata siswa SMKN 29 Jakarta.

\section{METODE PENELITIAN}

Metode penelitian berisi jenis penelitian, subjek atau objek penelitian, teknik pengumpulan, analisis data, dan keabsahan data. Penelitian ini menggunakan metode kuantitatif, studi tentang masalah sosial berdasarkan pada pengujian sebuah teori yang terdiri dari variabel-varibel, diukur menggunakan angka, serta dianalisis menggunakan prosedur statistik untuk menetapkan apakah generalisasi prediktif teori tersebut benar, merupakan 
penjelasan dari penelitian ini (Ulber Silalahi dalam Setiawan, 2016). Suatu asumsi dalam suatu gejala itu bisa diklasifikasikan serta hubungan gejala bersifat sebab akibat ataupun kausal, ini merupakan landasan dalam penelitian kuantitatif atau positivistik. Paradigma penelitian pada keadaan ini didefinisikan dengan pola pikir yang menampilkan kaitan antara variabel yang diteliti, yang sekaligus menggambarkan jenis serta jumlah rumusan masalah yang harus dijawab dengan penelitian, teori yang dipakai untuk merumuskan hipotesis, jenis dan jumlah hipotesis, serta teknik analisis statistik yang dipakai. (Sugiyono 2016)

Paradigma yang muncul paling awal pada ilmu pengetahuan adalah paradigma positivisme atau fungsionalis. Kepercayaan pandangan ini bersumber kepada paham "ontology realisme” yang mengatakan bahwa realitas ada pada kenyataan serta bergerak sesuai pada hukum alam. Penelitiannya mencoba mengungkap kebenaran dari realitas yang ada, serta bagaimana realitas itu bergerak sesuai pada kenyataan. Pada paradigma ini memilki perspektif yang didasari dengan sosiologi regulasi melalui pendekatan obyektif serta condong menganggap dunia sosial sebagai produk empiris yang nyata dan memiliki kaitan satu dengan yang lain atau sebab dan akibat (Diamastuti 2015).

\section{Teknik Pengumpulan Data}

Metode penelitian yang dipakai pada penelitian ini ialah metode survei dengan memakai kuesioner. Kuesioner bisa berupa pernyataan terbuka atau tertutup, bisa diberikan kepada responden dengan cara dikirim melalui pos atau internet ataupun secara langsung (Sugiyono dalam Setiawan, 2016). Mendapatkan data merupakan tujuan utama peneliti. Data pada penelitian ini diperoleh dengan dua cara, yaitu: (1) Data Primer, pada penelitian ini data primer didapat dari kuesioner yang disebarkan melalui Google form. Google form adalah platform yang disediakan oleh Google untuk membantu dalam penyebaran kuesioner melalui media digital agar lebih efisien. Jenis kuesioner yang digunakan dalam penelitian ini adalah kuesioner angket langsung tertutup. (2) Data Sekunder, Dalam penelitian ini terdiri dari buku-buku, jurnal, dan internet atau website yang terkait dengan penelitian untuk menunjang masalah yang dibahas dalam penelitian ini guna membantu mendapatkan informasi yang akurat.

\section{Populasi dan Sampel}

Teknik pengambilan sampel memakai teknik non probability sampling, dengan metode sampling sukarela (voluntary sampling). Sampel survei akhir dipilih dari calon responden yang 
sukarela dan memenuhi syarat dalam populasi sasaran (Murairwa 2015). Dalam pemilihan sampel penelitian, peneliti tidak bisa melanggar etika dan memaksa siapa saja yang akan menjadi sampel (Dwiastuti 2017). Populasi dari penelitian ini adalah siswa SMKN 29 Jakarta tahun ajaran 2020/2021 sebanyak 338 siswa. Pengambilan sampel dalam penelitian ini berlandaskan kerelaan siswa SMKN 29 Jakarta kelas 10 untuk berpartisipasi pada penelitian. Untuk menentukan minimal jumlah sampel digunakan rumus Taro Yamane dengan tingkat presisi sebesar $10 \%$, dan hasilnya sampel penelitian berjumlah minimal 78 siswa.

\section{Operasionalisasi Konsep}

Variabel bebas atau independen (X) adalah tayangan My Trip My Adventure dengan dimensi Morissan dalam Wulandari (2015): (1) Kesukaan, beberapa penonton memilih tayangan yang menampilkan pembawa acara atau pemain utama yang disukainya. (2) Konsistensi, sejak awal suatu program harus konsisten dengan tema dari karakter program yang disajikannya. (3) Energi, Vane-Gross mendefinisikan energi sebagai kualitas yang menekankan pada kecepatan dan semangat ke dalam cerita dengan menyajikan gambar-gambar yang tidak bisa ditinggalkan oleh penonton.

Variabel terikat atau dependen, variabel (Y) yakni, pengetahuan wisata dengan dimensi: Komponen dalam struktur sikap, menurut Walgito dalam Musrifah (2019), terdapat tiga komponen yang disusun serta saling berkaitan dengan masing-masing komponen. (Komponen perilaku) komponen konatif, (komponen emosional) komponen afektif, serta (komponen perseptual) komponen kognitif merupakan komponen dalam struktur sikap. 
Tabel 1 Operasionalisasi Konsep

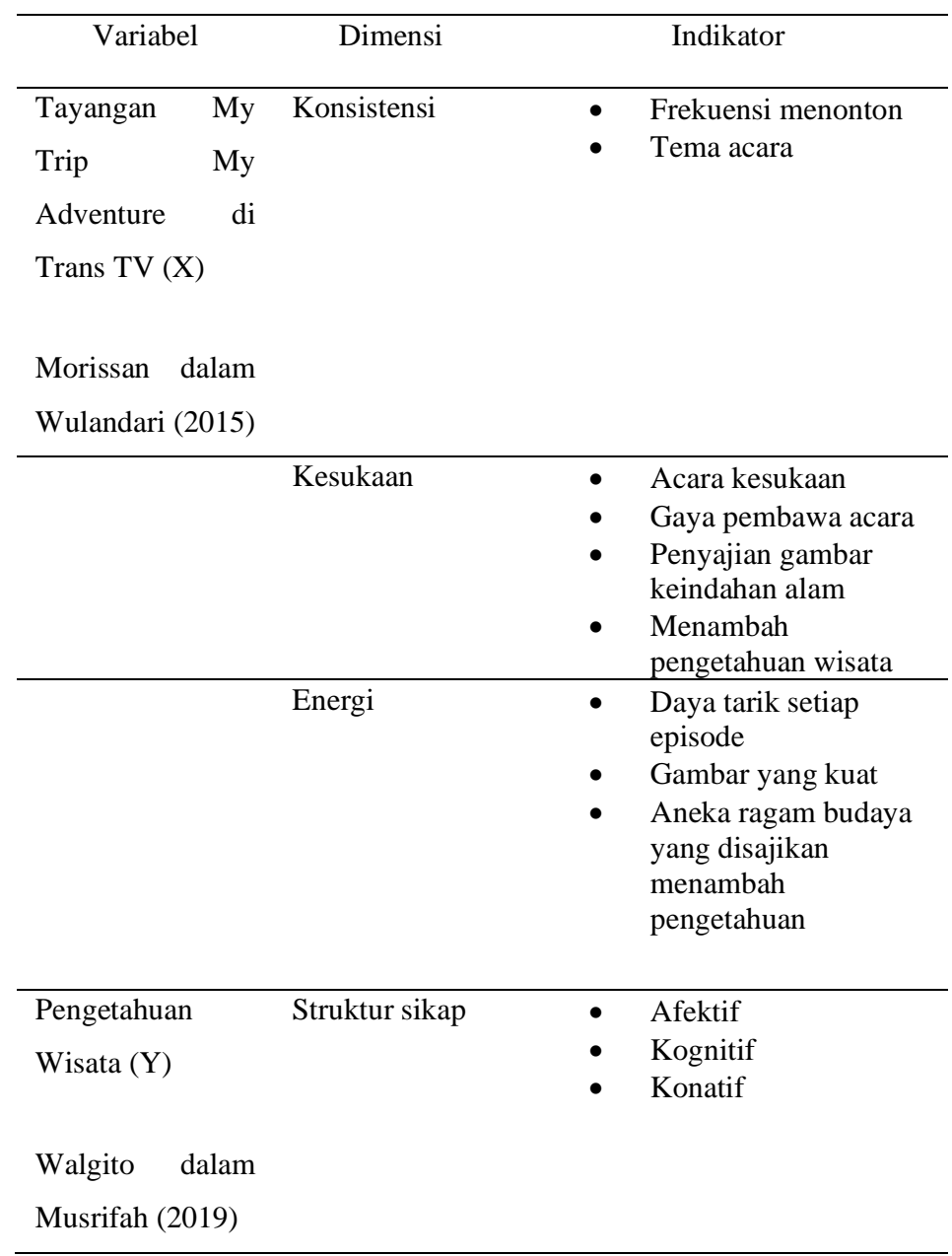

\section{Skala Pengukuran}

4 jenis skala pengukuran (Hardani et al. 2020): (a) Skala Nominal, pemakaian skala ini bermaksud untuk mengidentifikasi serta menghitung kejadian, subyek serta obyek untuk diklasifikasikan pada individu, perusahaan, merek, produk, atau entitas lain pada suatu kategori, sehingga sering disebut skala kategori. (b) Skala Ordinal dipakai dengan cara spesifik untuk pemeringkatan pada sebagian studi penelitian. Skala ordinal digunakan untuk menentukan tingkat persepsi konsumen, preferensi, kepuasan, dll. Beberapa uji statistik dapat diaplikasikan seperti kuartil, median, modus. (c) Skala Interval lebih berarti daripada skala ordinal atau nominal, sebab skala ini adalah representasi yang sama dari obyek yang diukur. Pemakaian skala ini memungkinkan peneliti mengetahui bagaimana objek-objek yang diteliti berbeda saat dibandingkan. (d) Skala Rasio adalah skala internal yang sifatnya khusus, sebab 
mempunyai titik nol yang bermakna. Skala rasio sering dipakai pada penghitungan jarak, berat, serta panjang.

Skala ordinal dengan menggunakan skala likert merupakan skala pengukuran data yang dipakai pada penelitian ini. Skala likert dipakai untuk mengukur pendapat, persepsi, dan sikap individu ataupun sekolompok orang tentang fenomena sosial. Pada penelitian fenomena sosial ini sudah ditetapkan dengan spesifik oleh peneliti yang selanjutnya disebut dengan variabel penelitian. Pada penelitian ini, peneliti menggunakan pertanyaan-pertanyaan yang dapat dijawab sesuai dengan jawaban-jawaban yang telah ditentukan. Bentuk jawaban dari kuesioner ini yaitu sebagai berikut. 5) $\mathrm{SS}=$ Sangat Setuju, 4) $\mathrm{S}=$ Setuju, 3) $\mathrm{N}=$ Netral, 2) TS=Tidak Setuju, 1) STS=Sangat Tidak Setuju. (Sugiyono 2016)

\section{Metode Analisis Data}

Hasil data diperoleh kemudian dianalisis menggunakan SPSS 26.0 dengan teknik analisis data sebagai berikut. (1) Statistik Deskriptif, memberi bayangan sesuatu data yang dilihat pada kemencengan distribusi (skewness), kurtosis, range, sum, minimum, maksimum, varian, standar deviasi, serta mean (nilai rata-rata) merupakan tujuan dari analisis statistik deskriptif (Ghozali 2018). Pengujian ini dilaksanakan untuk mempermudah ketika memahami variabelvariabel yang dipakai pada penelitian. (2) Uji Kualitas Data (a) Uji validitas dipakai untuk melihat valid tidaknya kuesioner. Ketika pernyataan pada kuesioner mampu untuk mengungkapkan sesuatu yang akan diukur oleh kuesioner tersebut, maka suatu kuesioner dinyatakan valid (Ghozali 2018). Ketika nilai signifikansi dibawah 0,05 (5\%) maka data dinyatakan valid. (b) Uji Reabilitas, merupakan uji yang dipakai untuk mengukur sebuah kuesioner yang menjadi indikator pada konstruk atau variabel. Sebuah kuesioner dinyatakan reliabel ketika jawaban responden pada pernyataan ialah stabil ataupun konsisten dari suatu waktu ke waktu lain (Ghozali 2018). Pengukuran reliabilitas bisa dilaksanakan melalui 2 cara, yakni: (Ghozali 2018) (a) Pengukuran ulang “Repeated Measure”, pada waktu yang berbeda, seseorang akan diberikan pernyataan yang sama, lalu dilihat apakah orang tersebut masih konsisten pada jawabannya. (b) Pengukuran sekali saja "One Shot", hasilnya hendak dikomparasi dengan pernyataan lainnya, untuk mengukur korelasi setiap jawaban di setiap pernyataannya. Kriteria pengujian dilaksanakan memakai Cronbach Alpha $(\alpha)$. Ketika nilai Cronbach Alpha > 0,60 suatu variable dinyatakan reliabel (Ghozali,2018). (3) Uji yang bermaksud untuk menguji apakah pada model regresi, variabel independen serta variabel 
dependen keduanya memiliki distribusi yang normal ataupun mendekati normal, disebut dengan uji normalitas. Ketika distribusi pada titik-titik data menyebar di sekitar garis diagonal serta penyebaran titik-titik data searah mengikuti garis diagonal maka suatu variabel dinyatakan normal. Pengujian pada penelitian inipun memakai uji "One Sample Kolmogorov Smirnov" yang mempunyai kriteria untuk normalitas dipenuhi ketika probabilitas signifikansi lebih besar dari 0,05 (Ghozali 2018). (4) Uji Hipotesis a) Analisis regresi linear sederhana, bertujuan menguji kedua variabel apakah berpengaruh antara Program My Trip My Adventure terhadap Pengetahuan wisata, uji hipotesisnya akan dilaksanakan memakai analisis statistik, dan memakai rumus regresi linear sederhana $\mathrm{Y}=\mathrm{a}+\mathrm{bX}$. Penjelasan: $\mathrm{Y}=$ subjek variabel Pengetahuan Wisata $X=$ subjek variabel Tayangan My Trip My Adventure a = konstanta (harga $\mathrm{Y}$ bila $\mathrm{X}=0$ ) $\mathrm{b}=$ koefisien regresi, yang menampakkan angka penurunan ataupun peningkatan variabel bebas (X) yang didasari atas hubungan variabel terikat (Y) (Friska 2016). b) (Uji Statistik t) Uji Signifikansi Parameter Individual, menguji sampai mana efek suatu variabel independen ataupun penjelas dengan cara individual pada saat menjelaskan variasi variabel dependen merupakan tujuan dari uji t. Hipotesis no (Ho) yang akan diuji ialah apakah sebuah parameter (bi) sama dengan nol: Ho : bi $=0$ definisinya apakah sebuah variabel independen tidak termaksud penjelas yang berarti pada variabel dependen. Hipotesis alternatif "HA" parameter sebuah variabel tidak sama dengan nol: HA : bi $\neq 0$ definisinya variabel itu adalah penjelas yang berarti pada variabel dependen (Ghozali 2018).

\section{METODE PENELITIAN}

Metode penelitian berisi jenis penelitian, subjek atau objek penelitian, teknik pengumpulan, analisis data, dan keabsahan data. Penelitian ini menggunakan metode kuantitatif, studi tentang masalah sosial berdasarkan pada pengujian sebuah teori yang terdiri dari variabel-varibel, diukur menggunakan angka, serta dianalisis menggunakan prosedur statistik untuk menetapkan apakah generalisasi prediktif teori tersebut benar, merupakan penjelasan dari penelitian ini (Ulber Silalahi dalam Setiawan, 2016). Suatu asumsi dalam suatu gejala itu bisa diklasifikasikan serta hubungan gejala bersifat sebab akibat ataupun kausal, ini merupakan landasan dalam penelitian kuantitatif atau positivistik. Paradigma penelitian pada keadaan ini didefinisikan dengan pola pikir yang menampilkan kaitan antara variabel yang diteliti, yang sekaligus menggambarkan jenis serta jumlah rumusan masalah yang harus 
dijawab dengan penelitian, teori yang dipakai untuk merumuskan hipotesis, jenis dan jumlah hipotesis, serta teknik analisis statistik yang dipakai. (Sugiyono 2016)

Paradigma yang muncul paling awal pada ilmu pengetahuan adalah paradigma positivisme atau fungsionalis. Kepercayaan pandangan ini bersumber kepada paham "ontology realisme" yang mengatakan bahwa realitas ada pada kenyataan serta bergerak sesuai pada hukum alam. Penelitiannya mencoba mengungkap kebenaran dari realitas yang ada, serta bagaimana realitas itu bergerak sesuai pada kenyataan. Pada paradigma ini memilki perspektif yang didasari dengan sosiologi regulasi melalui pendekatan obyektif serta condong menganggap dunia sosial sebagai produk empiris yang nyata dan memiliki kaitan satu dengan yang lain atau sebab dan akibat (Diamastuti 2015).

\section{Teknik Pengumpulan Data}

Metode penelitian yang dipakai pada penelitian ini ialah metode survei dengan memakai kuesioner. Kuesioner bisa berupa pernyataan terbuka atau tertutup, bisa diberikan kepada responden dengan cara dikirim melalui pos atau internet ataupun secara langsung (Sugiyono dalam Setiawan, 2016). Mendapatkan data merupakan tujuan utama peneliti. Data pada penelitian ini diperoleh dengan dua cara, yaitu: (1) Data Primer, pada penelitian ini data primer didapat dari kuesioner yang disebarkan melalui Google form. Google form adalah platform yang disediakan oleh Google untuk membantu dalam penyebaran kuesioner melalui media digital agar lebih efisien. Jenis kuesioner yang digunakan dalam penelitian ini adalah kuesioner angket langsung tertutup. (2) Data Sekunder, Dalam penelitian ini terdiri dari buku-buku, jurnal, dan internet atau website yang terkait dengan penelitian untuk menunjang masalah yang dibahas dalam penelitian ini guna membantu mendapatkan informasi yang akurat.

\section{Populasi dan Sampel}

Teknik pengambilan sampel memakai teknik non probability sampling, dengan metode sampling sukarela (voluntary sampling). Sampel survei akhir dipilih dari calon responden yang sukarela dan memenuhi syarat dalam populasi sasaran (Murairwa 2015). Dalam pemilihan sampel penelitian, peneliti tidak bisa melanggar etika dan memaksa siapa saja yang akan menjadi sampel (Dwiastuti 2017). Populasi dari penelitian ini adalah siswa SMKN 29 Jakarta tahun ajaran 2020/2021 sebanyak 338 siswa. Pengambilan sampel dalam penelitian ini berlandaskan kerelaan siswa SMKN 29 Jakarta kelas 10 untuk berpartisipasi pada penelitian. 
Untuk menentukan minimal jumlah sampel digunakan rumus Taro Yamane dengan tingkat presisi sebesar $10 \%$, dan hasilnya sampel penelitian berjumlah minimal 78 siswa.

\section{Operasionalisasi Konsep}

Variabel bebas atau independen (X) adalah tayangan My Trip My Adventure dengan dimensi Morissan dalam Wulandari (2015): (1) Kesukaan, beberapa penonton memilih tayangan yang menampilkan pembawa acara atau pemain utama yang disukainya. (2) Konsistensi, sejak awal suatu program harus konsisten dengan tema dari karakter program yang disajikannya. (3) Energi, Vane-Gross mendefinisikan energi sebagai kualitas yang menekankan pada kecepatan dan semangat ke dalam cerita dengan menyajikan gambar-gambar yang tidak bisa ditinggalkan oleh penonton.

Variabel terikat atau dependen, variabel (Y) yakni, pengetahuan wisata dengan dimensi: Komponen dalam struktur sikap, menurut Walgito dalam Musrifah (2019), terdapat tiga komponen yang disusun serta saling berkaitan dengan masing-masing komponen. (Komponen perilaku) komponen konatif, (komponen emosional) komponen afektif, serta (komponen perseptual) komponen kognitif merupakan komponen dalam struktur sikap.

Tabel 1 Operasionalisasi Konsep

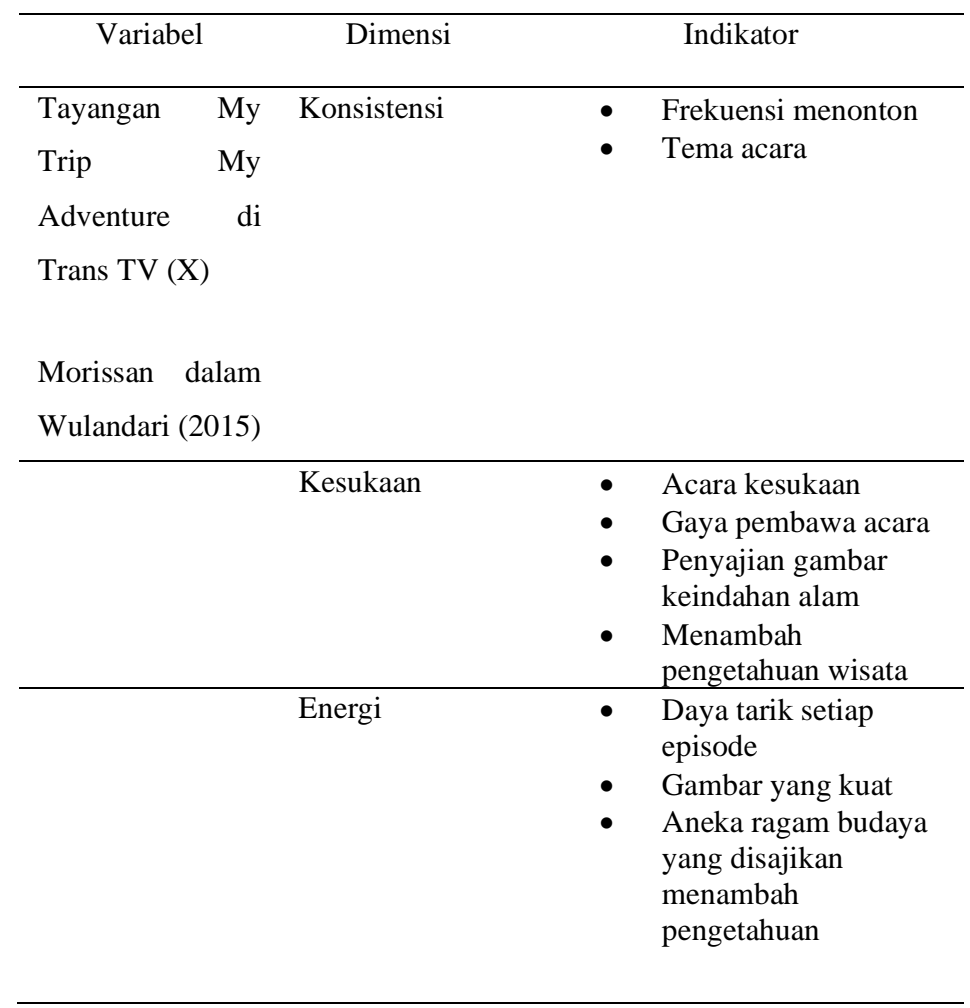




\begin{tabular}{|c|c|c|}
\hline $\begin{array}{l}\text { Pengetahuan } \\
\text { Wisata (Y) }\end{array}$ & Struktur sikap & $\begin{array}{ll}\text { - } & \text { Afektif } \\
\text { - } & \text { Kognitif } \\
\text { - } & \text { Konatif }\end{array}$ \\
\hline Walgito dalam & & \\
\hline Musrifah (2019) & & \\
\hline
\end{tabular}

\section{Skala Pengukuran}

4 jenis skala pengukuran (Hardani et al. 2020): (a) Skala Nominal, pemakaian skala ini bermaksud untuk mengidentifikasi serta menghitung kejadian, subyek serta obyek untuk diklasifikasikan pada individu, perusahaan, merek, produk, atau entitas lain pada suatu kategori, sehingga sering disebut skala kategori. (b) Skala Ordinal dipakai dengan cara spesifik untuk pemeringkatan pada sebagian studi penelitian. Skala ordinal digunakan untuk menentukan tingkat persepsi konsumen, preferensi, kepuasan, dll. Beberapa uji statistik dapat diaplikasikan seperti kuartil, median, modus. (c) Skala Interval lebih berarti daripada skala ordinal atau nominal, sebab skala ini adalah representasi yang sama dari obyek yang diukur. Pemakaian skala ini memungkinkan peneliti mengetahui bagaimana objek-objek yang diteliti berbeda saat dibandingkan. (d) Skala Rasio adalah skala internal yang sifatnya khusus, sebab mempunyai titik nol yang bermakna. Skala rasio sering dipakai pada penghitungan jarak, berat, serta panjang.

Skala ordinal dengan menggunakan skala likert merupakan skala pengukuran data yang dipakai pada penelitian ini. Skala likert dipakai untuk mengukur pendapat, persepsi, dan sikap individu ataupun sekolompok orang tentang fenomena sosial. Pada penelitian fenomena sosial ini sudah ditetapkan dengan spesifik oleh peneliti yang selanjutnya disebut dengan variabel penelitian. Pada penelitian ini, peneliti menggunakan pertanyaan-pertanyaan yang dapat dijawab sesuai dengan jawaban-jawaban yang telah ditentukan. Bentuk jawaban dari kuesioner ini yaitu sebagai berikut. 5) $\mathrm{SS}=$ Sangat Setuju, 4) $\mathrm{S}=$ Setuju, 3) $\mathrm{N}=$ Netral, 2) TS=Tidak Setuju, 1) STS=Sangat Tidak Setuju. (Sugiyono 2016)

\section{Metode Analisis Data}

Hasil data diperoleh kemudian dianalisis menggunakan SPSS 26.0 dengan teknik analisis data sebagai berikut. (1) Statistik Deskriptif, memberi bayangan sesuatu data yang dilihat pada kemencengan distribusi (skewness), kurtosis, range, sum, minimum, maksimum, varian, standar deviasi, serta mean (nilai rata-rata) merupakan tujuan dari analisis statistik deskriptif (Ghozali 2018). Pengujian ini dilaksanakan untuk mempermudah ketika memahami variabel- 
variabel yang dipakai pada penelitian. (2) Uji Kualitas Data (a) Uji validitas dipakai untuk melihat valid tidaknya kuesioner. Ketika pernyataan pada kuesioner mampu untuk mengungkapkan sesuatu yang akan diukur oleh kuesioner tersebut, maka suatu kuesioner dinyatakan valid (Ghozali 2018). Ketika nilai signifikansi dibawah 0,05 (5\%) maka data dinyatakan valid. (b) Uji Reabilitas, merupakan uji yang dipakai untuk mengukur sebuah kuesioner yang menjadi indikator pada konstruk atau variabel. Sebuah kuesioner dinyatakan reliabel ketika jawaban responden pada pernyataan ialah stabil ataupun konsisten dari suatu waktu ke waktu lain (Ghozali 2018). Pengukuran reliabilitas bisa dilaksanakan melalui 2 cara, yakni: (Ghozali 2018) (a) Pengukuran ulang “Repeated Measure”, pada waktu yang berbeda, seseorang akan diberikan pernyataan yang sama, lalu dilihat apakah orang tersebut masih konsisten pada jawabannya. (b) Pengukuran sekali saja "One Shot", hasilnya hendak dikomparasi dengan pernyataan lainnya, untuk mengukur korelasi setiap jawaban di setiap pernyataannya. Kriteria pengujian dilaksanakan memakai Cronbach Alpha $(\alpha)$. Ketika nilai Cronbach Alpha > 0,60 suatu variable dinyatakan reliabel (Ghozali,2018). (3) Uji yang bermaksud untuk menguji apakah pada model regresi, variabel independen serta variabel dependen keduanya memiliki distribusi yang normal ataupun mendekati normal, disebut dengan uji normalitas. Ketika distribusi pada titik-titik data menyebar di sekitar garis diagonal serta penyebaran titik-titik data searah mengikuti garis diagonal maka suatu variabel dinyatakan normal. Pengujian pada penelitian inipun memakai uji "One Sample Kolmogorov Smirnov" yang mempunyai kriteria untuk normalitas dipenuhi ketika probabilitas signifikansi lebih besar dari 0,05 (Ghozali 2018). (4) Uji Hipotesis a) Analisis regresi linear sederhana, bertujuan menguji kedua variabel apakah berpengaruh antara Program My Trip My Adventure terhadap Pengetahuan wisata, uji hipotesisnya akan dilaksanakan memakai analisis statistik, dan memakai rumus regresi linear sederhana $\mathrm{Y}=\mathrm{a}+\mathrm{bX}$. Penjelasan: $\mathrm{Y}=$ subjek variabel Pengetahuan Wisata $X=$ subjek variabel Tayangan My Trip My Adventure $a=$ konstanta (harga $\mathrm{Y}$ bila $\mathrm{X}=0$ ) $\mathrm{b}=$ koefisien regresi, yang menampakkan angka penurunan ataupun peningkatan variabel bebas (X) yang didasari atas hubungan variabel terikat (Y) (Friska 2016). b) (Uji Statistik t) Uji Signifikansi Parameter Individual, menguji sampai mana efek suatu variabel independen ataupun penjelas dengan cara individual pada saat menjelaskan variasi variabel dependen merupakan tujuan dari uji t. Hipotesis no (Ho) yang akan diuji ialah apakah sebuah parameter (bi) sama dengan nol: Ho : bi $=0$ definisinya apakah sebuah variabel independen tidak termaksud penjelas yang berarti pada variabel dependen. Hipotesis alternatif 
"HA" parameter sebuah variabel tidak sama dengan nol: HA : bi $\neq 0$ definisinya variabel itu adalah penjelas yang berarti pada variabel dependen (Ghozali 2018).

\section{PEMBAHASAN}

Berdasarkan data penelitian analisis deskriptif variabel tayangan My Trip My Aventure, ditemukan mayoritas responden dengan persentase jawaban setuju sebesar 56,3\% dan jawaban sangat setuju sebesar 32,2\%, berpendapat bahwa sajian gambar keindahan alam di acara My Trip My Adventure menampilkan potensi objek wisata Indonesia yang kaya keindahan alam. Selain itu mayoritas responden dengan persentase jawaban setuju sebesar 50,6\% dan jawaban sangat setuju sebesar 34,5\%, juga menyatakan bahwa mereka suka menonton acara My Trip My Adventure karena tayangan menyajikan keindahan alam serta petualangan.

Sedangkan hasil data penelitian analisis deskriptif variabel pengetahuan wisata, ditemukan mayoritas responden dengan persentase jawaban setuju sebesar 59,8\% dan jawaban sangat setuju sebesar 29,9\%, berpendapat bahwa acara My Trip My Adventure turut membawa pesan menjaga kebersihan lingkungan dan pelestarian alam. Selain itu mayoritas responden dengan persentase jawaban setuju sebesar 52,9\% dan jawaban sangat setuju sebesar 34,5\%, berpendapat bahwa pesan peduli lingkungan di acara My Trip My Adventure mengedukasi wisatawan untuk menjaga alam. Selanjutnya mayoritas responden lain dengan persentase jawaban setuju sebesar 41,4\% dan jawaban sangat setuju sebesar 37,9\% berpendapat tayangan My Trip My Adventure banyak memberi edukasi atau pengetahuan tentang wisata alam Indonesia. Selanjutnya mayoritas responden lain dengan persentase jawaban setuju sebesar 48,3\% dan jawaban sangat setuju sebesar 34,5\% berpendapat acara My Trip My Adventure memberi informasi berupa tempat-tempat wisata alam unik dan ragam budaya Indonesia. Selain itu mayoritas responden lain dengan persentase jawaban setuju sebesar 49,4\% dan jawaban sangat setuju sebesar 33,3\% berpendapat bahwa secara keseluruhan tayangan My Trip My Adventure merupakan tayangan yang sifatnya mendidik karena memperkenalkan sumber daya wisata alam daerah Indonesia.

Berdasarkan analisis data tayangan My Trip My Adventure memiliki pengaruh kuat dan signifikan terhadap pengetahuan wisata siswa. Hal ini ditunjukkan oleh nilai koefisien variabel $\mathrm{X}$ mempunyai tingkat signifikansi senilai 0,000 . Hal ini dapat diartikan bahwa penelitian ini mendukung hipotesis Ha, yaitu adanya pengaruh signifikan tayangan My Trip My Adventure terhadap pengetahuan wisata siswa, karena menghasilkan tingkat signifikansi $<0,05$. 
Sedangkan nilai R Square sebesar 0,682 atau 68,2\% yang menunjukkan tayangan My Trip My Adventure (X) memberikan pengaruh sebesar 68,2\% terhadap pengetahuan wisata siswa (Y), dan sisanya sebesar $31,8 \%$ dipengaruhi oleh faktor lain yang tidak diteliti di dalam penelitian ini.

\section{KESIMPULAN}

Penelitian ini menghasilkan kesimpulan yang ditarik dari hasil analisis dan pembahasan. Mayoritas responden berpendapat bahwa sajian gambar keindahan alam di acara My Trip My Adventure menampilkan potensi objek wisata Indonesia yang kaya keindahan alam. Mayoritas responden juga menyatakan bahwa mereka suka menonton acara My Trip My Adventure karena tayangan menyajikan keindahan alam serta petualangan. Berdasarkan hasil penelitian mayoritas responden juga setuju bahwa acara My Trip My Adventure turut membawa pesan menjaga kebersihan lingkungan dan pelestarian alam. Selain itu mayoritas responden berpendapat bahwa pesan peduli lingkungan di acara My Trip My Adventure mengedukasi wisatawan untuk menjaga alam. Secara keseluruhan berdasarkan hasil penelitian dan pembahasan tayangan My Trip My Adventure secara signifikan mempengaruhi pengetahuan wisata siswa.

\section{DAFTAR PUSTAKA}

\section{Buku}

Abdul Halik. 2013. Komunikasi Massa. ed. Muliati Amin. Makassar: Alauddin University Press. http://repositori.uin-alauddin.ac.id/338/1/KOMUNIKASI MASSA full.pdf.

Ardianto. 2014. Komunikasi Massa Suatu Pengantar. Bandung: Sembiosa Rekatama Media.

Dwiastuti, Rini. 2017. Metode Penelitian Sosial Ekonomi Pertanian. Malang: UB Press.

Ghozali, I. 2018. Aplikasi Analisis Multivariate Dengan Program IBM SPSS 25. Semarang: Universitas Diponegoro.

Hardani et al. 2020. Metode Penelitian Kualitatif \& Kuantitatif. Yogyakarta: Pustaka Ilmu.

Morissan, M.A. 2011. Manajemen Media Penyiaran: Strategi Mengelola Radio \& Televisi. Jakarta: Kencana Prenada Media Group.

Sugiyono. 2016. Metode Penelitian Kuantitatif, Kualitatif, Dan R\&D. Bandung: Alfabeta. 
Suwena, I Ketut, and I Gusti Ngurah Widyatmaja. 2017. Pengetahuan Dasar Ilmu Pariwisata. Denpasar: Pustaka Larasan.

\section{Jurnal}

Damasdino, Fian. 2015. "Studi Karakteristik Wisatawan Dan Upaya Pengembangan Produk Wisata Tematik Di Pantai Goa Cemara, Pantai Kuwaru, Dan Pantai Pandansimo Baru Kabupaten Bantul.” Jurnal Media Wisata 13(2).

Diamastuti, Erlina. 2015. "Paradigma Ilmu Pengetahuan Sebuah Telaah Kritis." Jurnal Akuntansi Universitas Jember 10(1): 61.

Friska, Novia. 2016. "Pengaruh Program My Trip My Adventure Transtv Terhadap Pengetahuan Wisata Di Kalangan Mahasiswa Program Studi Usaha Perjalanan Wisata (Upw) Fakultas Ilmu Sosial Dan Ilmu Politik Universitas Riau.” JOM FISIP 3(2).

Habibie, Dedi Kusuma. 2018. "Dwi Fungsi Media Massa.” Interaksi: Jurnal Ilmu Komunikasi 7(2): 79-86.

Hamdu, Ghullam, and Lisa Agustina. 2011. "Pengaruh Motivasi Belajar Siswa Terhadap Pestasi Belajar Ipa Di Sekolah Dasar.” Jurnal Penelitian Pendidikan 12(1).

Hartati, Sri. 2012. "Pendekatan Kognitif Untuk Menurunkan Kecenderungan Perilaku Deliquensi Pada Remaja." Humanitas 9(2).

Hermawan, Rudi, Arief Hidayat, and Victor Gayuh Utomo. 2016. "Sistem Informasi Penjadwalan Kegiatan Belajar Mengajar Berbasis Web." Indonesian Journal on Software Engineering Audit 2(1): 31-38.

Jayarni, Imra, and Dwi Septiwiharti. 2014. "Dampak Menonton Siaran Televisi Terhadap Prestasi Belajar Siswa Pada Mata Pelajaran Pkn Di Kelas IV SD Negeri 1 Posona Kecamatan Kasimbar." Jurnal Kreatif Tadulako Online 2(4): 101-14. http://jurnal.untad.ac.id/jurnal/index.php/JKTO/article/view/3981/2935.

Murairwa, Stanley. 2015. "Voluntary Sampling Design." International Journal of Advanced Research in ISSN: 2278-6236 Management and Social Sciences 4(2).

Musrifah. 2019. "Sikap Pemustaka Terhadap Pustakawan Setelah Berkomunikasi Di Perpustakaan Universitas Islam Negeri Sunan Kalijaga Yogyakarta.” Al Maktabah 4(2).

Mustika, Tias, and Rosita Anggraini. 2019. "Pengaruh Terpaan Media Terhadap Reputasi Lembaga Pemerintah.” Inter Script: Journal of Creative Communication 1(1): 66-79.

Nurchayati, Zulin. 2015. "Televisi Sebagai Media Komunikasi Massa Dan Pengaruhnya." SOSIAL 16(2).

Pratama, Deska Yoga, Ilham Mohamad Iqbal, and Nadiem Attar Tarigan. 2019. "Makna Televisi Bagi Generasi Z.” Inter Komunika : Jurnal Komunikasi 4(1): 88. 
Qudratullah. 2016. “Peran Dan Fungsi Komunikasi Massa.” Jurnal Tabligh: 41-46.

Setiawan, Mela Rizky. 2016. "Peranan Tayangan My Trip My Adventure Terhadap Perilaku Pelestarian Alam Di Kalangan Remaja (Studi Pada Tayangan Di Trans Tv Dan Remaja Di Jurusan Ilmu Komunikasi Fispol Unsrat Tahun Ajaran 2014/2015)." e-journal "Acta Diurna” V(3).

Soedarso, Muchammad Nurif, and Windiani. 2014. "Potensi Dan Kendala Pengembangan Pariwisata Berbasis Kekayaan Alam Dengan Pendekatan Marketing Places (Studi Kasus Pengembangan Pariwisata Di Kabupaten Bojonegoro).” jsh Jurnal Sosial Humaniora $7(2)$.

Wulandari, Tine Agustin. 2015. "Mendongkrak Keberhasilan Program Televisi Di Indonesia Melalui Akun Pada Situs Jejaring Sosial Twitter." Jurnal Ilmu Politik dan Komunikasi $\mathrm{V}(2)$. 